\title{
PELAYANAN PEREKAMAN KARTU TANDA PENDUDUK ELEKTRONIK DI KANTOR KECAMATAN KANOR KABUPATEN BOJONEGORO (STUDI TENTANG KUALITAS PELAYANAN PUBLIK)
}

\author{
Ahmad Suprastiyo \\ Fakultas Ilmu Sosial dan Ilmu Politik, Universitas Bojonegoro \\ Jl. Lettu Suyitno No 2 Bojonegoro \\ Email : tiyopras207@gmail.com
}

\begin{abstract}
Abstrak
Peningkatan kualitas pelayanan publik menjadi perhatian penting untuk pemerintah, hal ini dibuktikan dengan ditetapkannya Undang-Undang Nomor 25 Tahun 2009 tentang Pelayanan Publik. Pelayanan perekaman kartu tanda penduduk elektronik merupakan pelayanan administrasi yang diberikan pemerintah untuk warga negaranya. Namun, realita dilapangan pelayanan perekaman KTP elektronik di Kantor Kecamatan Kanor belum sesuai dengan harapan masyarakat dalam mendapatkan pelayanan publik, hal ini dapat dijelaskan dari kurangnya kecepatan pelayanan, kesopanan dan keramahan petugas pelayanan, kompetensi pelaksana, serta sarana dan prasarana di ruang pelayanan. Penelitian ini bertujuan untuk mengetahui dan menjelaskan pelayanan perekaman kartu tanda penduduk elektronik di Kantor Kecamatan Kanor (studi tentang kualitas pelayanaan publik). Metode penelitian yang digunakan dengan pendekatan kualitatif dan pendekatan kuantitatif (mix method). Penentuan informan menggunakan purposive snowball sampling. Analisis data menggunakan data collection, data reduction, data display, and conclusion drawing/verifying. Hasil penelitian menunjukkan bahwa kualitas pelayanan perekaman kartu tanda penduduk elektronik di kantor Kecamatan Kanor dari aspek sarana dan prasarana, kompetensi pelaksana dan perilaku pelaksana baik, namun dari aspek waktu pelayanan lambat (tidak baik).
\end{abstract}

Kata kunci : Kualitas Pelayanan Publik, Administrasi Kependudukan

\begin{abstract}
Improving the quality of public services is an important concern for the government, this is evidenced by the enactment of Law Number 25 of 2009 concerning Public Services. The recording service for electronic resident identification cards is an administrative service provided by the government to its citizens. However, the reality in the field of electronic ID card recording service at Kanor District Office is not in accordance with the expectations of the community in obtaining public services, this can be explained from the lack of service speed, courtesy and friendliness of service personnel, implementing competence, and facilities and infrastructure in the service room. This study aims to find out and explain the service of recording electronic identity cards in the Kanor sub-district office (study of the quality of public service). The approach mix method in which qualitative data generalised through whislt quantitative data. Determination of informants using purposive snowball sampling. Data analysis uses data collection, data reduction, data display, and conclusion drawing / verifying. The results showed that the service quality of electronic resident card recording at the District Office of Kanor was from the aspect of infrastructure and facilities, implementing competence and good implementation behavior, but from the aspect of slow service time (not good).
\end{abstract}

Keywords: Quality of Public Services, Population Administration 


\section{PENDAHULUAN}

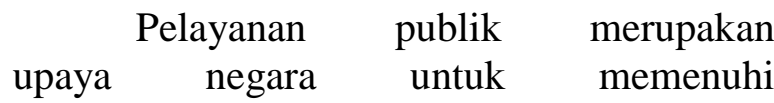
kebutuhan dasar dan hak-hak sipil setiap warga negara atas barang, jasa dan pelayanan administrasi yang disediakan oleh penyelenggara pelayanan publik. dengan demikian dapat didefinisikan bahwa

Penyelenggara pelayanan publik ialah instansi pemerintah yang merupakan sebutan kolektif meliputi satuan kerja/ satuan organisasi Kementerian, Departemen, Lembaga Pemerintah Non Departemen, Kesekretariatan Lembaga Tertinggi dan Tinggi Negara, dan Instansi Pemerintah lainnya, baik Pusat maupun Daerah termasuk Badan Usaha Milik Negara, Badan Hukum Milik Negara dan Badan Usaha Milik Daerah. Sedangkan pemberi pelayanan publik adalah pejabat/pegawai instansi pemerintah yang melaksanakan tugas dan fungsi pelayanan publik sesuai dengan peraturan perundang-undangan.

$$
\text { Hakikat pelayanan publik }
$$
merupakan pemberian pelayanan prima atau peningkatan kualitas pelayanan kepada masyarakat yang merupakan perwujudan kewajiban aparatur pemerintah sebagai abdi masyarakat. Didalam pelaksanaan pelayanan publik, kepentingan masyarakat selalu menjadi hal yang utama. Pelayanan publik yang prima berarti pelayanan yang mampu memuaskan pelanggan, yang mana kepuasan ini tercipta apabila kebutuhan dan keinginan masyarakat sebagai pelanggan/ penerima layanan terpenuhi. Kepuasan masyarakat dapat menjadi indikator apakah pelayanan yang diberikan sudah dilaksanakan dengan baik.

Seiring dengan berkembangnya jaman, masyarakat semakin kritis menuntut adanya pelayanan publik yang berkualitas dan dapat memenuhi harapan serta kebutuhan mereka. Masyarakat juga menuntut adanya keterbukaan dalam pelayanan yang diberikan mulai dari persyaratan, biaya, proses, waktu yang diperlukan hingga kepastian hukum dari produk layanan yang diberikan, sehingga pemerintah dituntut untuk melaksanakan berbagai strategi dalam menyelenggarakan pelayanan berkualitas. Diantara strategi tersebut adalah pengembangan sistem dan prosedur yang transparan dan sederhana, pemanfaatan teknologi informasi, pengembangan sumber daya pegawai, pengembangan sarana dan prasarana pelayanan serta penyediaan sarana pengaduan dan tempat informasi bagi penerima layanan.

$$
\text { Pelayanan administrasi }
$$

kependudukan merupakan bagian dari pelayanan publik di bidang administrasi. Administrasi kependudukan adalah rangkaian kegiatan penataan dan penertiban dalam penerbitan dokumen dan data kependudukan melalui pendaftaran penduduk, pencatatan sipil, pengelolaan informasi administrasi kependudukan serta pendayagunaan hasilnya untuk pelayanan publik dan pembangunan sektor lain. Salah satu bentuk dokumen kependudukan di Indonesia adalah Kartu Tanda Penduduk (KTP) yang wajib dimiliki oleh setiap penduduk Warga Negara Indonesia dan orang asing yang memiliki Izin Tinggal Tetap yang telah berumur 17 (tujuh belas) tahun atau telah kawin atau pernah kawin.

Pelayanan Perekaman Kartu Tanda Penduduk Elektronik Salah satu bentuk pelayanan publik adalah pelayanan di bidang administrasi kependudukan. Undang-Undang No. 24 Tahun 2013 tentang Administrasi Kependudukan pada Pasal 1 ayat 1 menyebutkan bahwa : Administrasi kependudukan adalah rangkaian kegiatan penataan dan penertiban dalam penerbitan dokumen dan data kependudukan melalui pendaftaran penduduk, pencatatan sipil, pengelolaan informas 
administrasi kependudukan serta pendayagunaan hasilnya untuk pelayanan publik dan pembangunan sektor lain.

Peraturan Menteri Dalam Negeri Nomor 9 Tahun 2011 tentang Pedoman Penerbitan KTP Berbasis Nomor Induk Kependudukan Secara Nasional pada pasal 1 menyebutkan bahwa KTP adalah identitas resmi penduduk sebagai bukti diri yang diterbitkan Dinas Kependudukan dan Pencatatan Sipil Kabupaten/ Kota yang berlaku di seluruh wilayah Negara Kesatuan Republik Indonesia. KTP berbasis Nomor Induk Kependudukan (NIK) secara nasional yang disebut dengan KTP Elektronik adalah KTP yang memiliki spesifikasi dan format KTP nasional dengan sistem pengamanan khusus yang berlaku sebagai identitas resmi yang diterbitkan oleh Dinas Kependudukan dan Pencatatan Sipil Kabupaten/ Kota. KTP elektronik ini memuat data penduduk yang meliputi biodata, foto diri, rekaman sidik jari-jari, rekaman iris mata dan tanda tangan elektronik. NIK yang tercantum pada KTP elektronik ini bersifat unik dan tunggal yang melekat pada pada seseorang yang terdaftar sebagai penduduk Indonesia.

Peningkatan kualitas pelayanan publik menjadi perhatian penting bagi pemerintah dan hal ini dibuktikan dengan ditetapkannya Undang-Undang Nomor 25 Tahun 2009 tentang Pelayanan Publik, yang mana ruang lingkup pelayanan publik meliputi pelayanan barang publik, jasa publik dan administratif yang diatur dalam peraturan perundang-undangan. Pelayanan adminitratif ini meliputi : (a) Tindakan administratif pemerintah yang diwajibkan oleh negara dan diatur dalam peraturan perundang-undangan dalam rangka mewujudkan perlindungan pribadi, keluarga, kehormatan, martabat, dan harta benda warga Negara, (b) Tindakan administratif oleh instansi non pemerintah yang diwajibkan oleh negara dan diatur dalam peraturan perundang-undangan serta diterapkan berdasarkan perjanjian dengan penerima pelayanan, sebagaimana menuntut adanya peningkatan kualitas pelayanan publik yang diselenggarakan oleh pemerintah.

Kualitas pelayanan merupakan perbandingan antara kenyataan atas pelayanan yang diterima dengan harapan atas pelayanan yang ingin diterima, Conin dalam Afrial (2009:88), Sedangkan menurut Parasuraman, Zeithaml, dan Berry dalam Samosir (2005:28), kualitas pelayanan adalah perbandingan yang diharapkan konsumen dengan pelayanan yang diterimanya. Dari pengertian tersebut dapat dipahami bahwa masyarakat dalam memberikan penilaian terhadap kualitas pelayanan berdasarkan perbandingan pengalaman yang pernah dirasakan dengan apa yang diharapkan atas pelayanan tersebut.

Prinsip-prinsip layanan yang berkualitas menurut H.A.S. Moenir (2002:205) antara lain: (a) proses dan prosedur harus ditetapkan lebih awal, (b) proses dan prosedur itu harus diketahui oleh semua pihak yang terlibat, (c) disiplin bagi pelaksanaan untuk mentaati proses dan prosedur (d) perlu peninjauan proses dan prosedur oleh pimpinan, sewaktuwaktu dapat dirubah apabila perlu. (e) perlu menciptakan iklim yang kondusif bagi pengembang budaya organisasi untuk menciptakan kualitas layanan, (f) kualitas berarti memenuhi keinginan, kebutuhan, selera konsumen, (g) setiap orang dalam organisasi merupakan partner dengan orang lainnya. Sedangkan Levince dalam Ratminto dan Winarsih (2006:175) melihat kualitas pelayanan dari indikator-indikator sebagai berikut: (1) Responsiveness (responsivilitas) ialah ini mengukur daya tanggap providers terhadap harapan, keinginan, dan aspirasi, serta tutuntutan dari costumers, (2) Responsibility (responsibilitas) ialah Suatu ukuran yang menunjukkan seberapa jauh proses pemberian pelayanan publik itu dilakukan dengan 
tidak melanggar ketentuanketentuan yang telah ditetapkan, (3) Accountability (akuntabilitas) ialah suatu ukuran yang menunjukkan seberapa besar tingkat keseuaian antara penyelenggara pelayanan dengan ukuran-ukuran eksternal yang ada dimasyarakat dan dimiliki oleh stakeholders, seperti nilai dan norma yang berkembang dalam masyarakat.

Akan tetapi realita dilapangan pelayanan perekaman KTP elektronik di Kantor Kecamatan Kanor Kabupaten Bojonegoro yang telah dilaksankan mulai tahun 2012 belum sesuai dengan harapan masyarakat dalam mendapatkan pelayanan publik, hal ini dapat dijelaskan dari kurangnya kecepatan pelayanan dikarenakan belum adanya standar waktu pelayanan mulai awal pelayanan sampai dengan produk pelayanan selesai, sehingga tidak ada waktu yang pasti terhadap produk layanan itu selesai, bahkan setelah proses perekaman KTP elektronik selesai, pemohon terkadang juga harus menunggu lebih lama untuk mendapatkan surat pengantar yang dibutuhkan.

Selanjutnya untuk kesopanan dan keramahan petugas pada saat melayani pemohon misalnya jarang tersenyum serta memberi perintah atau aba-aba dengan nada kurang ramah di saat perekaman data. Dalam pelayanan prima seharusnya pihak pemberi layanan memberikan perhatian dan menunjukkan kesopanan mulai saat pemohon datang sampai akan meninggalkan ruangan. Kemudian untuk kompetensi pelaksana jumlah pegawai yang mempunyai kompetensi dalam pelayanan perekaman kartu tanda penduduk elektronik masih kurang hanya berjumlah 4 (empat) orang dan dari 4 (empat) orang tersebut 2 (orang) sering diminta untuk melakukan pekerjaan di unit lain juga, sehingga dalam memberikan pelayanan tidak bisa optimal. Sedangkan untuk sarana dan prasarana pelayanan dapat diobservasi dengan adanya pemohon yang harus menunggu sambil berdiri karena bangku tunggu yang disediakan di dalam ruangan sudah penuh. Kekurangan tersebut juga tampak dengan adanya pemohon yang tampak berkeringat karena gerah terutama pada saat siang hari. Di dalam pelayanan publik yang berkualitas, seharusnya ketersediaan sarana dan prasarana yang memadai menjadi hal yang diutamakan.

Sesuai dengan Peraturan Menteri Pendayagunaan Aparatur Negara dan Reformasi Birokrasi Nomor 16 Tahun 2014 tentang Pedoman Survei Kepuasan Masyarakat Terhadap Penyelenggaraan Pelayanan Publik, ruang lingkup survei kepuasan masyarakat meliputi (1)persyaratan adalah syarat yang harus dipenuhi dalam pengurusan suatu jenis pelayanan, baik persyaratan teknis maupun administratif, (2)Prosedur adalah tata cara pelayanan yang dibakukan bagi pemberi dan penerima pelayanan, termasuk pengaduan, (3)Waktu pelayanan adalah jangka waktu yang diperlukan untuk menyelesaikan seluruh proses pelayanan dari setiap jenis pelayanan, (4)Biaya/Tarif adalah ongkos yang dikenakan kepada penerima layanan dalam mengurus dan/atau memperoleh pelayanan dari penyelenggara yang besarnya ditetapkan berdasarkan kesepakatan antara penyelenggara dan masyarakat, (5)Produk spesifikasi jenis pelayanan adalah hasil pelayanan yang diberikan dan diterima sesuai dengan ketentuan yang telah ditetapkan. Produk pelayanan ini merupakan hasil dari setiap spesifikasi jenis pelayanan, (6)Kompetensi Pelaksana adalah kemampuan yang harus dimiliki oleh pelaksana meliputi pengetahuan, keahlian, keterampilan, dan pengalaman, (7)Perilaku Pelaksana adalah sikap petugas dalam memberikan pelayanan, (8)Maklumat Pelayanan adalah merupakan pernyataan kesanggupan dan kewajiban penyelenggara untuk melaksanakan pelayanan sesuai dengan standar pelayanan, 
(9)Penanganan pengaduan, saran dan masukan, adalah tata cara pelaksanaan penanganan pengaduan dan tindak lanjut.

Berdasarkan dari beberapa fenomena yang terjadi, penelitian ini bertujuan untuk mengetahui dan menjelaskan pelayanan perekaman kartu tanda penduduk elektronik di kantor Kecamatan Kanor Kabupaten Bojonegoro (studi tentang kualitas pelayanaan publik).

\section{METODE PENELITIAN}

Jenis penelitian yang digunakan ialah penelitian deskriptif dengan pendekatan kualitatif dan pendekatan kuantitatif (mix method). Penelitian ini berlokasi di Kantor Kecamatan Kanor Kabupaten Bojonegoro. Fokus penelitian ini ialah waktu pelayanan, sarana dan prasarana, kompetensi pelaksana, perilaku pelaksana. Pengambilan informan penelitian menggunakan teknik snowball sampling, dalam proses penelitian terinventarisir sumber data primer sebanyak 34 informan yang terdiri dari : 1) Kepala Seksi Pelayanan Umum berjumlah 1 orang, 2) Operator Sistem Informasi Administrasi Kependudukan (SIAK) berjumlah 4 orang, 3) Pemohon KTP Elektronik 29 orang. Sumber data yang digunakan adalah sumber data primer dan data sekunder dengan cara observasi, wawancara mendalam dan dokumentasi. Dalam menganalisa menggunakan teknik analisis data interaktif Model miles and Huberman, yang mengemukakan bahwa "aktifitas dalam analisis data kualitatif dilakukan secara interaktif dan berlangsung secara terus menerus sampai tuntas. Aktifitas dalam analisis data, yaitu data reduction, data display and conclusion drawing/verifying" (dalam Sugiyono 2013 : 404). Teknik keabsahan data dalam penelitian ini adalah ketekunan pengamatan dan triangulasi sumber.

\section{HASIL PENELITIAN DAN \\ PEMBAHASAN \\ Waktu Pelayanan}

Pelayanan yang berkualitas harus dapat dilakukan sesuai dengan target waktu yang telah ditetapkan sehingga pengguna layanan (citizen) tidak membutuhkan waktu tunggu yang lama dalam mendapatkan pelayanan. Berdasarkan wawancara dengan petugas pelayanan KTP elektronik bahwa kecepatan waktu pelayanan KTP elektronik di Kecamatan Kanor menunjukkan bahwa kecepatan waktu pelayanan KTP elektronik belum baik (masih lambat dalam berikan pelayanan), dikarenakan belum ada standar waktu pelayanan mulai awal pelayanan sampai dengan produk pelayanan selesai. Selain itu juga (1)banyaknya pelayanan yang harus ditangani ruang pelayanan umum sedangkan petugas pelayanan jumlahnya terbatas, (2)pejabat yang berwenang menandatangani surat pengantar cetak KTP tidak berada di tempat, (3)dua orang staf dari seksi lain yang diperbantukan di ruang pelayanan umum tidak dapat selalu membantu pelaksanaan pelayanan yang diharapkan karena mereka juga mempunyai banyak tugas di seksinya masing-masing, (4)listrik padam yang menyebabkan seluruh peralatan tidak dapat digunakan dan kegiatan pelayanan terhenti, (5)gangguan jaringan Sistem Administrasi Kependudukan sehingga proses entri data tidak dapat berjalan, (6)jumlah peralatan perekaman KTP elektronik hanya satu set. Jika ada salah satu jenis peralatan yang bermasalah maka pelayanan tidak dapat dilakukan karena harus menunggu sampai selesai diperbaiki. Hal ini juga sesuai dengan pernyataan responden bahwa dari 34 responden pihak masyarakat pemohon KTP elektronik, 9 mengatakan kecepatan waktu pelayanan KTP elektronik yang diberikan cepat, 7 responden mengatakan sedang dan 18 responden lainnya mengatakan lambat sebagaimana tabel 1 berikut : 
Tabel 1

Waktu Pelayanan KTP Elektronik di Kantor Kecamatan Kanor

\begin{tabular}{lccc}
\hline No & Responden & Jumlah & Prosentase (\%) \\
1 & Cepat & 9 & 26,47 \\
2 & Sedang & 7 & 20,59 \\
3 & Lambat & 18 & 52,94 \\
& Jumlah & 34 & 100 \\
\hline
\end{tabular}

Sumber : Data yang diolah peneliti, 2018

\section{Sarana dan Prasarana Pelayanan}

Dalam mewujudkan pelayanan yang berkualitas diperlukan sarana dan prasarana yang memadai untuk kelancaran pelaksanaan pekerjaan dan kenyamanan warga masyarakat pengguna layanan. Berdasarkan wawancara dengan petugas pelayanan KTP elektronik bahwa sarana dan prasarana pelayanan KTP elektronik dikantor kecamatan kanor sudah baik, telah memenuhi standar pelayanan. Akan tetapi pada saat jam sibuk dimana banyak antrian pelayanan, maka jumlah bangku tunggu tersebut tidak dapat menampung jumlah pemohon yang datang. Apalagi jika warga yang datang tersebut tidak sendirian, tetapi sambil membawa anak kecil atau diantar teman atau saudaranya yang tentunya menambah jumlah orang yang membutuhkan tempat duduk di dalam ruangan, selain itu terkait suhu ruangan yang agak panas memang dari dua unit AC di ruang pelayanan umum hanya satu unit yang dinyalakan. Hal ini dikarenakan satu unit lainnya dalam kondisi kurang baik. Hal ini menyebabkan kemampuan menyejukkan ruangan kurang maksimal terutama pada siang hari dan terdapat banyak orang di dalam ruangan. Adapun data sekunder peralatan dan perlengkapan di ruang pelayanan umum sebagaimana tabel 2 berikut

Tabel 2

Peralatan dan Perlengkapan di Ruang Pelayanan Umum

\begin{tabular}{clcl}
\hline No. & \multicolumn{1}{c}{ Nama Barang } & Jumlah & \multicolumn{1}{c}{ Kondisi } \\
1 & Komputer & 5 & 4 baik, 1 rusak \\
2 & Printer Kartu Keluarga (KK) & 1 & baik \\
3 & Printer & 2 & 1 baik, 1 rusak \\
4 & Pemindai dokumen & 1 & Baik \\
5 & Modem wifi & 1 & Baik \\
6 & Regulator & 1 & Baik \\
7 & Server & 1 & Baik \\
8 & Meja server & 1 & Baik \\
9 & Kamera & 1 & Baik \\
10 & Perekam tanda tangan & 1 & Baik \\
11 & Pemindai sidik jari & 1 & Baik \\
12 & Pemindai iris mata & 1 & Baik \\
13 & Layar background foto & 2 & Baik \\
14 & Kursi Kerja & 5 & Baik \\
15 & Lemari arsip & 2 & Baik \\
16 & Meja pelayanan & 4 & Baik \\
\hline
\end{tabular}




\begin{tabular}{llll}
\hline 17 & Meja tulis & 1 & Baik \\
18 & Bangku tunggu & 3 & Baik \\
19 & Pendingin ruangan (AC) & 2 & 1 baik, 1 kurang baik \\
20 & Televisi & 1 & Baik \\
21 & Tempat air minum & 1 & Baik \\
22 & Cermin & 1 & Baik \\
23 & Jam dinding & 1 & Baik \\
\hline
\end{tabular}

Sumber: Data perlengkapan Kantor Kecamatan Kanor, 2018

Berdasarkan data tersebut ruang pelayanan umum di Kantor Kecamatan Kanor dilengkapi dengan sarana dan prasarana yang cukup untuk pelaksanaan pekerjaan maupun untuk kenyamanan masyarakat yang datang. Tetapi jika dilihat dari data peralatan yang digunakan untuk perekaman KTP elektronik, yaitu kamera, pemindai sidik jari, pemindai iris mata dan perekam tanda tangan hanya terdapat satu set peralatan saja. Hal ini berpotensi menimbulkan kendala saat terjadi kerusakan yang menyebabkan terhambatnya pelayanan karena tidak ada cadangan peralatan. Demikian pula dengan printer yang digunakan untuk mencetak surat pengantar, hanya terdapat satu unit printer yang dalam kondisi bagus. Hal ini berpotensi menimbulkan kendala jika printer tersebut mengalami kerusakan sehingga tidak dapat digunakan. Kendala lainnya adalah saat akan digunakan untuk mencetak surat pengantar KTP elektronik, printer tersebut sedang digunakan mencetak dokumen- dokumen lainnya.

Hal ini juga dibuktikan dari 34 responden pihak masyarakat pemohon KTP elektronik di kantor Kecamatan Kanor, 20 responden mengatakan bahwa sarana dan prasarana yang disediakan sudah baik, 8 responden mengatakan cukup dan 6 responden mengatakan kurang. Dalam hal ini dapat dikatakan bahwa kualitas pelayanan perekaman KTP elektronik dari aspek sarana dan prasarana atau fasilitas yang ada dapat dikatakan baik sebagaimana tabel 3 berikut :

\section{Tabel 3}

Sarana dan Prasarana Pelayanan KTP Elektronik di Kantor Kecamatan Kanor

\begin{tabular}{lccc}
\hline No & Responden & Jumlah & Prosentase (\%) \\
1 & Baik & 20 & 58,82 \\
2 & Cukup baik & 8 & 23,53 \\
3 & Kurang baik & 6 & 17,65 \\
& Jumlah & 34 & 100 \\
\hline
\end{tabular}

Sumber : Data yang diolah peneliti, 2018.

\section{Kompetensi Pelaksana}

Salah satu aspek yang dinilai dari kualitas suatu pelayanan ialah kompetensi pelaksana adalah kemampuan yang harus dimiliki oleh pelaksana meliputi pengetahuan, keahlian, keterampilan, dan pengalaman. Kualitas pelayanan KTP elektronik di kantor Kecamatan Kanor dari aspek kompetensi pelaksana berdasarkan wawancara dengan Kepala Seksi Pelayanan Umum bahwa kompetensi petugas pelaksana pelayanan KTP elektronik sudah baik (menguasai). Adapun data sekunder pegawai yang bertugas di seksi pelayanan umum sebagaimana tabel 4 berikut : 


\section{Tabel 4}

Data Pegawai yang Bertugas di Seksi Pelayanan Umum

\begin{tabular}{|c|c|c|c|}
\hline No & Jabatan & Pendidikan & Keterangan \\
\hline 1 & Kepala Seksi & $\mathrm{S} 1$ & $\begin{array}{l}\text { Penanggung jawab } \\
\text { pelayanan umum }\end{array}$ \\
\hline 2 & $\begin{array}{l}\text { Staf administrasi } \\
\text { umum/ operator } 1\end{array}$ & SMA & Staf seksi Pelayanan Umum \\
\hline 3 & $\begin{array}{l}\text { Staf administrasi } \\
\text { umum/ operator } 2\end{array}$ & SMA & Staf seksi Pelayanan Umum \\
\hline 4 & Operator 3 & SMA & Staf seksi Pemerintahan \\
\hline 5 & Operator cadangan & SMA & Satpol PP \\
\hline
\end{tabular}

Sumber : Diolah dari data Kepegawaian Kantor Kecamatan Kanor, 2018

Berdasarkan tabel di atas dapat dijelaskan bahwa pegawai yang berasal dari seksi pelayanan umum sendiri hanya ada tiga orang, yaitu satu orang Kepala Seksi dan dua orang staf administrasi yang sekaligus juga operator Sistem Administrasi Kependudukan. Dua orang staf yang diperbantukan dari ruangan lain tentunya juga mempunyai tugas yang berkaitan langsung dengan tupoksinya di seksinya masing-masing. Hal ini menimbulkan kendala dalam memberikan pelayanan jika di saat yang sama mereka harus menyelesaikan banyak tugas dari seksinya masing-masing. Selain itu tidak ada staf yang ditunjuk sebagai petugas pendukung pelayanan yang dapat membantu operator dalam menyelesaikan tugas sehingga operator dapat fokus pada kegiatan entri data. Hal ini menimbulkan potensi masalah, yaitu jika terjadi antrian pelayanan, maka operator tidak dapat menyelesaikan tugasnya dengan cepat.

Hal tersebut juga didukung oleh pernyataan responden, 29 responden mengatakan bahwa operator mempunyai kompetensi baik (menguasai) sedangkan sisanya sejumlah 5 responden mengatakan bahwa kompetensi petugas kurang baik (kurang menguasai) serta tidak ada responden yang menganggap bahwa petugas tidak menguasai. Dari hasil tersebut dapat dikatakan bahwa kualitas pelayanan dari aspek kompetensi pelaksana dapat dikatakan baik (menguasai) sebagaimana tabel 5 berikut.

Tabel 5

Kompetensi Pelaksana Pelayanan KTP Elektronik di Kantor Kecamatan Kanor

\begin{tabular}{cccc}
\hline No & Responden & Jumlah & Prosentase (\%) \\
1 & Menguasai & 29 & 85,29 \\
2 & Kurang menguasai & 5 & 14,71 \\
3 & Tidak menguasai & 0 & 0 \\
& Jumlah & 34 & 100 \\
\hline
\end{tabular}

Sumber : Data yang diolah peneliti, 2018

\section{Perilaku Pelaksana}

Perilaku pelaksana merupakan salah satu aspek yang dinilai dari kualitas pelayanan publik, sikap petugas dalam memberikan pelayanan untuk pengguna layanan mempunyai nilai penting terhadap kepuasan masyarakat. Berdasarkan wawancara dengan Kepala Seksi Pelayanan Umum bahwa perilaku petugas pelaksana pelayanan KTP elektronik sudah baik, tercermin dari perilaku petugas yang hormat, ramah, sopan dan santun. 
Hal tersebut juga didukung oleh pernyataan responden, 28 responden mengatakan bahwa perilaku petugas hormat, ramah, sopan dan santun, 5 responden mengatakan perilaku petugas kurang hormat, ramah, sopan dan santun, dan 1 responden mengatakan perilaku petugas tidak hormat, ramah, sopan dan santun. Dari hal tersebut dapat dijelaskan bahwa kualitas pelayanan dari aspek perilaku pelaksana dapat disimpulkan, perilaku petugas pelaksana dalam memberikan pelayanan hormat, ramah, sopan dan santun, sebagaimana tabel 6 berikut.

Tabel 6

Perilaku Pelaksana Pelayanan KTP Elektronik di Kantor Kecamatan Kanor

\begin{tabular}{clcc}
\hline No & \multicolumn{1}{c}{ Responden } & Jumlah & Prosentase (\%) \\
1 & $\begin{array}{l}\text { Hormat, Ramah, Sopan } \\
\text { dan Santun }\end{array}$ & 28 & 82,35 \\
2 & $\begin{array}{l}\text { Kurang Hormat, Ramah, } \\
\text { Sopan dan Santun } \\
\text { Tidak Hormat, Ramah, } \\
\text { Sopan dan Santun } \\
\quad \text { Jumlah }\end{array}$ & 1 & 14,71 \\
& 34 & 2,94 \\
\hline
\end{tabular}

Sumber: Data yang diolah peneliti

\section{KESIMPULAN}

Dari termuan-temuan dalam penelitian ini, dapat disimpulkan bahwa kualitas pelayanan publik pada pelayanan perekaman kartu tanda penduduk elektronik di kantor Kecamatan Kanor berdasarkan Peraturan Menteri Pendayagunaan Aparatur Negara dan Reformasi Birokrasi Nomor 16 Tahun 2014 Tentang Pedoman Survei Kepuasan Masyarakat Terhadap Penyelenggaraan Pelayanan Publik yang mana fokus penelitian ini pada 4 (empat) aspek survei kepuasan masyarakat yaitu waktu pelayanan, sarana dan prasarana, kompetensi pelaksana dan perilaku pelaksana, menunjukkan bahwa kualitas pelayanan perekaman kartu tanda penduduk elektronik di kantor Kecamatan Kanor dari aspek sarana dan prasarana, kompetensi pelaksana dan perilaku pelaksana baik, namun dari aspek waktu pelayanan lambat (tidak baik).

\section{SARAN}

Berdasarkan kesimpulan tersebut, maka rekomendasi yang dapat diusulkan ialah pihak kecamatan kanor harus membuat dan menetapkan standar pelayanan perekaman kartu tanda penduduk elektronik yang mencangkup komponen persyaratan pelayanan, prosedur, waktu pelayanan, biaya/tarif, produk layanan dan pengelolaan pengaduan. Selain itu, untuk menjaga konsistensi penyelenggara pelayanan pihak kecamatan kanor harus menetapkan maklumat pelayanan sebagai pernyataan kesanggupan dan kewajiban penyelenggara untuk melaksanakan pelayanan sesuai dengan standar pelayanan. Penambahan jumlah staf yang ditugaskan di ruang pelayanan umum juga perlu dilakukan untuk menambah kecepatan proses pelayanan yang diberikan dengan cara menugaskan staf seksi Tramlinmas/ Satpol PP sebagai staf pendukung pelayanan yang membantu tugas operator SIAK. 


\section{DAFTAR PUSTAKA}

Afrial, R, 2009, "Kualitas Pelayanan Publik Kecamatan Sebuah Perubahan Kedudukan dan Fungsi Camat Sebagai Perangkat Daerah", Jurnal Adminstrasi dan Organisasi.

Djam'an Satori dan Aan Komariah, 2009."Metodologi Penelitian Kualitatif" Alfabeta, Bandung.

Hardiyansyah, 2011, Kualitas Pelayanan Publik Konsep, Aspek, Indikator, dan Implementasinya, Gaya Media, Yogyakarta.

Sugiyono, 2013 "Metode Penelitian Manajemen" Alfabeta, Bandung.

Sumber Lain :

Peraturan Menteri Dalam Negeri Nomor 9 Tahun 2011 Tentang Pedoman Penerbitan Kartu Tanda Penduduk Berbasis Nomor Induk Kependudukan Secara Nasional
Peraturan Bupati Bojonegoro Nomor 08 Tahun 2009 Tentang Tugas Pokok dan Fungsi Kecamatan dan Kelurahan Kabupaten Bojonegoro

Peraturan Daerah Kabupaten Bojonegoro Nomor 09 Tahun 2008 Tentang organisasi dan Tata Kerja Kecamatan dan Kelurahan Kabupaten Bojonegoro

Peraturan Menteri Pendayagunaan Aparatur Negara dan Reformasi Birokrasi Nomor 16 Tahun 2014 Tentang Pedoman Survei Kepuasan Masyarakat Terhadap Penyelenggaraan Pelayanan Publik

Undang-Undang Nomor 25 Tahun 2009 Tentang Pelayanan Publik.

Undang-Undang Nomor 24 Tahun 2013 Tentang Perubahan Atas UndangUndang Nomor 23 Tahun 2006 tentang Administrasi Kependudukan 